\title{
Kompetensi Profesional bagi Seorang Guru dalam Manajemen Kelas
}

\author{
Sudjoko S. \\ Pendidikan Bahasa Inggris, STKIP Kusuma Negara, Indonesia \\ djokosingo@stkipkusumanegara.ac.id
}

\begin{abstract}
For a profesional teacher should master a class-management, especially, knows about the management functions. There are as follows; planning, directing, acting, organizing and controlling. Planning consists of curriculum, educational callender, learning schedule, semester program, and lesson plan, and they are mastered by a profesional teacher. Learning directing should succeed and pass a scoring target, mastering all of materials, learning methods, strategy and learning approaches. After finishing all of learning and teaching processes, then it is to evaluate and analysis to make a good program on the other time. The objective of this research is how to improve compentence teacher in classes management by using discussing method in this research. The research method uses of the classroom action research; it concists of two cycles, and each cycle uses four steps. They are planing, acting, actuating and reflecting.
\end{abstract}

Keywords: planning, directing, acting, organizing, and controlling.

Dikirim: 7 Februari 2020

Direvisi: 17 Juni 2020

Diterima: 24 Juni 2020

Identitas Artikel:

Sudjoko, S. (2020). Kompetensi Profesional bagi Seorang Guru dalam Manajemen Kelas. Jurnal Ilmu Pendidikan (JIP) STKIP Kusuma Negara, 12(1), 1-15.

\section{PENDAHULUAN}

Kompetensi yang harus dimiliki bagi seorang guru atau pendidik adalah sebagai berikut: 1) kompetensi pedagogik, 2) kompetensi kepribadian 3) kompetensi sosial, dan 4) kompetensi profesional. Kompetensi profesional bagi seorang guru atau pendidik adalah sebuah tuntutan sebagai profesinya, bukan hanya menguasai materi yang akan diajarkan namun harus memahami betul tentang pengelolaan pembelajaran atau manajemen kelas. Karena berhubungan dengan manajemen maka tentu harus memahami betul tentang fungsi manajemen itu sendiri, agar pengelolaan pembelajaran dapat dijalankan lebih efektif dan efesien serta meraih sukses.

Pengelolaan pembelajaran di dalam kelas perlu dikelola dengan baik agar pembelajaran berhasil secara optimal. Pengelolaan atau manajemen kelas memiliki fungsi manajemen yang sama telah dikemukakan oleh Henry Fayol (dalam Yuliani, Suntoro \& Kandar, 2015) antara lain: planning, organizing, staffing, directing, dan controlling. Seorang pendidik yang profesional harus memahami dan dapat menerapkan dengan baik fungsi manajemen tersebut agar hasil pekerjaannya lebih efektif dan efesien. Kemungkinan untuk seorang guru yang berpengalaman telah memahami dan menguasai betul tentang fungsi manajemen tersebut, karena hampir setiap awal semester gasal ataupun semester genap selalu mempersiapkan perangkat pembelajaran yang meliputi: 1) kurikulum 
atau silabus, 2) kalender pendidikan, 3) jadwal pelajaran, 4) program semester dan 5) Rencana Pelaksanaan Pembelajaran (RPP); yang didalamnya syarat dengan penentuan tujuan pembelajaran, penyusunan materi yang harus diajarkan sesuai silabus, penentuan metode, teknik, model, pendekatan pembelajaran dan soal tes untuk pre-test atau postest. Namun untuk guru baru atau mahasiswa yang sedang mempersiapkan program pengalaman lapangan (PPL) untuk RPP masih mengalami banyak kendala atau masalah.

Proses kegiatan pembelajaran yang dikelola dengan baik akan menghasilkan pekerjaan yang baik, apalagi perencanaan pembelajaran cukup kredibel. Karena sebenarnya, pada kegiatan pembelajaran tersebut, seorang guru atau pendidik dituntut untuk dapat melaksanakan perencanaan pembelajaran dengan baik. Bagi seorang guru harus memahami betul bagaimana pengelolaan kelas yang baik, penataan tempat duduk siswa, yang kecil atau pendek ditempatkan di depan, sedangkan yang tinggi di belakang. Demikian juga untuk siswa yang mengalami pandangan mata tidak normal atau jereng ke kanan maka ditempatkan di sebelah kiri guru, sebaliknya yang jereng kekiri ditempatkan di sebelas kanan guru, diharapkan siswa tersebut bisa sembuh karena kepedulian pengelolaan guru di kelas tersebut.

Seorang guru profesional dituntut dapat membentuk kelompok (staffing) agar dapat bersaing dalam pembelajaran antara kelompok yang satu dengan yang lain. Kelompok-kelompok tersebut bila seorang guru sebagai fasilitator tentu dapat membuat iklim belajar menjadi hidup dan menyenangkan. Seorang guru atau pendidik bisa sebagai pengarah karena ia bisa mengarahkan (directing) bila terjadi deadline. Sebagai contoh bila dalam diskusi antar kelompok tersebut akan terjadi saling marah atau saling bermusuhan, maka seorang guru harus dapat memberikan arahan agar dapat menghindari hal-hal yang tidak diinginkan, maka dibuat tata tertib sebagai kesepakatan antar kelompok. Hal yang tak dapat dihindari, seorang guru atau pendidik harus bisa sebagai supervisor atau pengawas, maka dapat mengamati, mengkontrol (controlling) jalannya pembelajaran

Pada akhir kegiatan pembelajaran, seorang guru atau pendidik bisa menganalisis apa kekurangan ataupun kelebihan selama pelaksanaan pembelajaran, baik mulai dari perencanaan pembelajaran, proses kegiatan pembelajaran hingga hasil belajar peserta didik. Dalam pembelajaran, biasanya ditentukan berapa kriteria ketuntasan minimal (KKM) yang harus dicapai dimana peserta didik tersebut dianggap lulus dalam pembelajaran materi tersebut. Di sisi lain, juga ditentukan berapa target belajar bagi peserta didik di kelas yang diampu, biasanya ditentukan antara $80 \%$ hingga $100 \%$. Dengan demikian, peserta didik akan mudah di analisis berapa persen (\%) yang tertinggal, harus diberikan remedial atau kebijakan lainnya.

Banyak terjadi di lapangan, mahasiswa sebagai calon guru atau pendidik yang akan terjun ke PPL harus menyiapkan RPP, dan mengikuti micro-teaching, ada yang sempurna menyiapkan RPP namun pada saat micro-teaching, ia nervous tidak percaya diri sehingga apa yang dilakukan dalam kegiatan pembelajaran tidak sesuai dengan RPP yang disiapkan. Sebaliknya, ada pula seorang mahasiswa tingkat akhir menyiapkan RPP tidak begitu baik, namun pada saat melakukan pembelajaran dalam micro-teaching sangat baik dan menguasai kelas, menguasai materi yang diajarkan, bisa mengatur waktu dengan baik, bisa menggunakan metode pembelajaran dengan baik. 


\section{Manajemen Kelas}

Terminologi manajemen adalah suatu kegiatan untuk mengkoordinir dan efektifitas pekerjaan yang dilakukan sehingga kegiatan tersebut akan lebih lengkap, efektif dan efesien melalui orang lain. Hal ini sesuai pendapat Robbins \& Coulter (2007) dalam buku berjudul "Management" bahwa "The term management refers to the process of coordinating and integrating work activities so that they are completed efficiently and effectively with and through other people. Let's look at some of the speciffic parts of this definition."

Seorang pakar manajemen yakni Henri Fayol (dalam Yuliani dkk., 2015), mengkategorikan bahwa fungsi manajemen sebagai berikut: 1) perencanaan (planning), 2) pengorganisation (organizing), 3) pengadministrasian (staffing), 4) tujuan (directing), dan 5) pengawasan (controlling). Fungsi manajemen tersebut dapat digunakan sebagai kerangka kerja (framework) bagi pimpinan sebagai pemegang kebijakan, sampai kepada pelaksana pekerjaan di lapangan. Setiap pengelolaan suatu organisasi, baik perusahaan, sekolah, universitas hingga organisasi sekecil apapun termasuk pengelolaan kelas, maka perlu penerapan fungsi manajemen agar pencapaian dan penyelesaian pekerjaan bisa sukses melalui proses yang efektif dan efesien.

Namun demikian, bila diperhatikan pada bagian makna yang lebih khusus, kegiatan tersebut merupakan fungsi berkelanjutan atau kegiatan-kegiatan yang senantiasa dilakukan oleh para manajer. Fungsi manajemen yang dimaksud adalah perencanaan, pengorganisasian, kepemimpinan, dan pengawasan. Kita bisa elaborasi terhadap fungsi-fungsi manajemen tersebut dan melaksanakan kegiatan manajemen pada seksi berikutnya, sebagaimana yang dlakukan para manajer. Hal ini persis yang dikatakan Robbins \& Coulter (2007) bahwa "The process represents the ongoing functions or primary activities engaged in by manegers. These functions are typically labeled planning, organizing, leading, and controlling. We elaborate on these functions and the process of management in the next section as we look more closely at what managers do."

Kelas merupakan sentra atau pusat interaksi antara guru atau pendidik dengan para peserta didiknya yang memiliki tujuan. Tujuan pembelajaran tersebut dapat dicapai dengan mudah tentu melalui strategi, metode pembelajaran, teknik hingga pendekatan melalui model pembelajaran yang sesuai dengan materi pembelajaran yang diajarkan, dan telah dipersiapkan sebelumnya.

Berdasarkan pendapat dari para pakar tersebut, maka dapat disintesiskan bahwa manajemen kelas perlu untuk dikelola dengan baik sesuai dengan kebutuhan. Terutama disesuaikan dengan model, metode, strategi, media pembelajaran yang akan digunakan untuk proses pembelajaran yang lebih efektif dan efesien.

\section{Profesi Guru}

Profesi adalah jenis pekerjaan seseorang yang dikuasai dengan baik bahkan harus memiliki berbagai kemampuan atau kompetensi yang harus dikuasai pada setiap tugas atau pekerjaan yang diembannya. Sebagai contoh; seorang tukang kayu jelas bahwa si tukang kayu tersebut harus mampu, membaca gambar atau sketsa yang akan dibuat atau contoh sebuah pintu, ia mampu mengukur kayu yang dibutuhkan dengan baik, menggergaji, memahat, memasah, merangkaikan pekerjaan yang 
harus diselesaikan, hingga finishing untuk pintu atau hasil pekerjaan dengan sempurna.

Guru atau pendidik sebagai profesi, memiliki status yang sama dengan profesi yang lain. Sesungguhnya, guru sering disebut sebagai orang tua kandung dari profesi lainnya. Hal ini dapat dipahami bahwa seorang guru atau pendidik sering menghasilkan profesi lainnya. Seorang guru seyogyanya, dapat menggunakan kompetensinya didalam kelas, menciptakan suasana kelas yang kondusif, aktif melalui diskusi, debat yang terarah sehingga terjadi interaksi yang kuat antara guru dan peserta didiknya.

Seorang guru dituntut untuk memiliki kemampuan atau kompetensi mengajar pada bidang studi yang diampunya. Hal ini bukan hanya menguasai materi yang akan diajarkan kepada peserta didik, namun harus mampu merancang program pembelajaran yang baik, menyiapkan materi, metode, model, pendekatan, strategi pembelajaran, melaksanakan proses pembelajaran dengan baik, menguasai pengelolaan atau manajemen kelas dengan baik, dan bahkan mampu mengevaluasi setelah kegiatan pembelajaran usai. Bahkan harus mampu menentukan solusi apa yang harus dilakukan terhadap hasil pembelajaran yang masih kurang, dan mampu mengarsipkan hasil pembelajaran yang sukses sebagai acuan pada kegiatan selanjutnya. Guru dituntut untuk menguasai betul tentang tujuan pembelajaran; respon peserta didik setelah menerima materi pembelajaran.

Di sisi lain, seorang guru dituntut bukan hanya mampu mengajarkan materi yang telah disiapkan namun bila merujuk pada tujuan pendidikan, maka seorang guru juga harus bisa mendidik sikap yang baik kepada peserta didiknya. Oleh karena itu, secara langsung seorang guru harus dapat mengkategorikan mana yang harus diajarkan sesuai kemampuan (cognitive), sikap (affective), hingga perilaku (psycomotoric) anak didik yang diajarnya.

\section{Kompetensi Pendidik}

Seorang guru dituntut memiliki kompetensi dalam melaksanakan tugas dan pekerjaan baik sebelum memasuki kelas, tatap muka bersama anak didik hingga akhir pembelajaran harus berhasil dengan baik. Kompetensi merupakan tindakan atau perilaku yang rasional untuk mencapai tujuan yang telah dicanangkan sesuai aturan yang berlaku. Kompetensi guru atau pendidik dapat dikatakan sebagai kemampuan guru atau pendidik dalam melaksanakan tugas dan pekerjaan secara bertanggung jawab dan pantas dalam melaksanakannya. Kompetensi secara hakekat kualitatif bagi guru atau pendidik yang diwujudkan penuh bermakna, sama halnya menurut pendapat Burke \& Stone (1975) bahwa "Descriptive of qualitative nature or teacher behavior appears to be entirely meaningful."

Menurut Undang-Undang RI No 14 Tahun 2005, tentang Guru dan Dosen, bahwa seorang guru atau dosen harus memiliki kompetensi antara lain sebagai berikut: 1) kompetensi pedagogik, 2) kompetensi kepribadian, 3) kompetensi sosial, dan 4) kompetensi profesional. Sedangkan Peraturan Pemerintah No 74 tahun 2008, tentang guru pada pasal (2) disebutkan bahwa guru wajib memiliki kualifikasi akademik, kompetensi, sertifikasi pendidik, sehat jasmani dan rohani, serta memiliki kemampuan untuk mewujudkan tujuan pendidikan nasional. Kompetensi adalah seperangkat pengetahuan, keterampilan, dan perilaku yang harus dimiliki, dihayati, dikuasai dan diaktualisasi oleh guru atau pendidik dalam melaksanakan tugas profesionalnya. 


\section{Kompetensi Profesional}

Kompetensi profesional adalah kemampuan bagi seorang guru atau pendidik secara mendalam dalam melaksanakan tugas pekerjaan. Seorang guru atau pendidik yang profesional harus memahami tentang fungsi manajemen, agar dapat melaksanakan tugas pembelajaran secara efektif dan efesien. Fungsi manajemen tersebut antara lain; perencanaan, pengorganisation, pengadministrasian, tujuan, dan evaluasi. Jelas bahwa seorang guru atau pendidik harus bisa mengelola manajemen kelas dengan baik, harus mampu mengarahkan peserta didiknya agar dengan kemampuan mereka bisa terkordinir dengan baik.

Di lain pihak, seorang guru atau pendidik yang profesional harus memahami tentang: 1) perencanaan; bagaimana untuk penyiapan kurikulum, kalender akademik, dan jadwal pelajaran, selanjutnya dapat menyusun program semester, rencana pembelajaran, menyiapkan tujuan pembelajaran, materi, metode, model, strategi, pendekatan, maupun media pembelajaran; 2) memahami betul tentang proses kegiatan pembelajaran, langkah-langkah pembelajaran yang akan dilalui, mulai dari pre-test, kegiatan awal, kegiatan inti, kegiatan akhir hingga post-test, menciptakan suasana belajar yang kondusif, senang; 3) bisa mengadministrasikan dengan baik seluruh kegiatan pembelajaran, menyusun laporan hasil belajar peserta didik; 4) bisa menganalisis hasil belajar peserta didiknya.

\section{Motivasi Belajar}

Motivasi belajar adalah dorongan yang kuat bagi siswa untuk belajar. Dorongan tersebut bisa dorongan dari luar (excentric) dan dorongan dari dalam (incentric). Menurut Sudjoko (2015), motivasi kerja pegawai adalah dorongan kekuatan yang ada dalam diri seseorang baik dari luar maupun dari dalam untuk lebih semangat dalam menyelesaikan target pekerjaan di suatu Organisasi. Dorongan atau kekuatan tersebut baik dorongan dari luar atau dari dalam diri dosen sendiri. Dorongan untuk bersinergi dengan; institusi, rekan sekerja, pimpinan, waktu yang efektif, dorongan ingin tahu; berbagai teknik, media, membaca, ICT, dorongan untuk mendapatkan reward, bersaing dalam pekerjaan, karier, pangkat dan golongan, dorongan rasa tanggung jawab; menentukan dan memilih pekerjaan yang paling penting, membuat program kerja, mendidik, meneliti, dan mengabdi pada masyarakat, evaluasi pekerjaan.

\section{Tujuan Penelitian}

Tujuan utama dalam penulisan karya ilmiah ini diharapkan dapat membantu meningkatkan kemampuan untuk mahasiswa tingkat akhir yang akan memasuki dunia pembelajaran di sekolah dasar hingga sekolah menengah. Karya ilmiah ini pula diharapkan dapat membantu untuk mengingatkan seorang guru atau pendidik sebagai profesi dalam pekerjaannya harus memahami dan mengetahui betul tentang kompetensi guru yang harus dikuasai, agar tugas pekerjaannya bisa lebih sukses dan optimal.

Diharapkan karya ilmiah ini dapat menambah khasanah ilmiah dan wawasan untuk seorang guru atau pendidik sebagai profesi pekerjaannya, dan bagaimana agar benar-benar profesional dalam melaksanakan tugas pokoknya. Oleh karena penguasaan kompetensi profesional, diharapkan seorang guru atau pendidik memahami betul tentang pengelolaan pembelajaran atau manajemen kelas agar 
lebih efektif dan efesien, sehingga berhasil untuk mencerdaskan anak didiknya. Untuk menjadi seorang guru yang profesional dalam melaksanakan tugasnya, harus memahami dan menguasai tentang fungsi manajemen untuk diimplementasikan di lapangan atau di ruang kelas.

\section{METODE PENELITIAN}

Metode penelitian yang digunakan adalah survey menggunakan penelitian tindakan kelas di kelas micro-teaching bagi mahasiswa yang akan mengikuti PPL. Perangkat apa saja yang harus disiapkan oleh calon peserta sebelum mengikuti dan melaksanakan PPL di sekolah yang dituju. Dengan menggunakan perangkat tersebut secara lengkap, maka proses pelaksanaan di lapangan akan lebih mudah. Di sisi lain, melalui pendekatan kualitatif terutama wawancara, diskusi, classroom action research bagaimana meningkatkan hasil belajar dan didukung penelitian pustaka (library reseach).

\section{HASIL DAN PEMBAHASAN}

\section{Kurikulum atau Silabus}

Periode 2014-2015, kurikulum yang digunakan di sekolah-sekolah dasar hingga sekolah menengah pertama maupun sekolah menengah atas, masih banyak menggunakan Kurikulum Tingkat Satuan Pelajaran (KTSP). Baru pada pertengahan tahun 2016, mengawali menggunakan kurikulum tahun dua ribu tiga belas (Kurtilas) bagi sekolah dasar, sekolah menengah pertama maupun sekolah menengah atas.

Memperhatikan permasalahan Kurikulum KTSP tersebut maka Kementerian Pendidikan dan Kebudayaan telah mengembangkan sebagai penyempurnaan yakni Penyusunan Kurikulum 2013. Kurikulum 2013 (Kurtilas) tersebut digunakan sebagai menu pembelajaran dapat pula digunakan sebagai acuan dan pedoman dalam perencanaan, proses kegiatan hingga evaluasi dalam pembelajaran. Menu atau muatan dalam kurikulum tersebut antara lain sebagai berikut: kompetensi dasar, indikator, materi pembelajaran, kegiatan pembelajaran, penilaian, alokasi waktu dan sumber belajar. Setiap guru atau pendidik wajib untuk memahami dan dapat menggunakan kurikulum tersebut dengan baik, sebagai menu yang akan disajikan bagi peserta didik dalam proses pembelajaran. Oleh sebab itu bagi seorang pendidik harus memiliki kompetensi baik sesuai dengan latar belakang pendidikannya, ataupun pernah mengikuti pelatihanpelatihan khusus tentang penggunaan kurikulum tersebut.

\section{Kalender Pendidikan}

Kalender Pendidikan atau kalender akademik, biasanya telah disiapkan oleh dinas pendidikan, karena disesuaikan dengan jadwal secara wilayah ataupun tingkat nasional. Untuk sekolah-sekolah negeri biasanya seorang pendidik dapat langsung menggunakan kalender tesebut. Sedangkan untuk sekolah-sekolah swasta biasanya sekolah atau Yayasan Pendidikan dapat memodifikasi kalender tersebut dengan tidak merubah program dinas pendidikan, namun program pendidikan di sekolah swasta tersebut menyesuaikan dengan program dinas pendidikan tersebut. Dengan memperhatikan kalender pendidikan, maka seorang guru dapat 
menentukan kapan hari-hari efektif belajar, kapan guru menyiapkan soal-soal ujian, kapan ujian akhir semester dan seterusnya.

\section{Jadwal Pelajaran}

Jadwal pelajaran adalah jadwal kegiatan pembelajaran yang dilaksanakan di kelas. Jadwal kegiatan pembelajaran diatur berapa tatap muka antara guru atau pendidik dengan peserta didiknya dilakukan setiap hari dalam satu minggu atau lima hari efektif yakni antara hari Senin sampai dengan hari Jum'at. Berapa menit jumlah satu jam pelajaran, biasanya satu jam pelajaran berisi 40 sampai dengan 50 menit. Bagaimana untuk setiap mata pelajaran dijadwalkan dalam satu minggu atau lima hari belajar efektif.

\section{Program Semester}

Program semester adalah tentang bagaimana kegiatan pembelajaran yang efektif dilakukan dalam satu semester, mulai proses kegiatan pembelajaran hingga kapan dilakukan kegiatan ujian tengan semester, hingga kapan dilakukan ujian akhir semester. Program semester tersebut bila disusun dengan baik maka rekam jejak setiap mata pelajaran dalam satu semester dapat dilihat dengan jelas. Bagaimana bila hari pertemuan mata pelajaran tersebut tepat tanggal merah atau hari libur misalkan tanggal 17 Agustus, maka pertemuan tatap muka dapat digantikan pada hari efektif berikutnya.

\section{Rencana Pelaksanaan Pembelajaran (RPP)}

RPP adalah cermin kegiatan yang akan dilakukan bagaimana proses kegiatan pembelajaran agar berhasil baik, melalui kriteria ketuntasan minimal belajar hingga mencapai target belajar yang diharapkan. Untuk mempersiapkan RPP maka dibutuhkan dapat membaca dan menelaah kurikulum atau silabus dengan baik. Seorang pendidik harus dapat merancang RPP tersebut dengan baik dan dapat diterapkan di lapangan atau di kelas pembelajaran.

Yang harus diperhatikan dalam penyusunan RPP adalah bagaimana menentukan tujuan dan target pembelajaran yang akan dicapai. Demikian pula untuk pelaksanaan proses pembelajaran apakah sesuai dengan tujuan dan target pembelajaran. Pada akhirnya, hasil pembelajaran dapat tercapai sesuai dengan target atau bahkan lebih atau melampaui target yang akan diterapkan.

\section{Kegiatan Pembelajaran}

Kegiatan pembelajaran adalah sebuah proses atau kegiatan interaksi antara seorang pendidik atau guru dengan para peserta didiknya. Proses kegiatan interaksi antara peserta didik dan pendidik yang dilengkapi dengan menu materi belajar yang telah dipersiapkan sesuai dengan silabus atau kurikulum bagi sekolah yang bersangkutan. Melalui proses kegiatan interaksi tersebut peserta didik dapat mengalami perubahan segala kompetensi mereka, baik kemampuan dalam ranah kognitif, affektif maupun psikomotorik.

Sistematika kegiatan pembelajaran dilaksanakan secara baik, diawali dengan pretes, analisis kesulitan atau masalah jawaban-jawaban pretes tersebut. Pemecahan-pemecahan masalah pada materi yang telah diujikan awal, penjelasan pokok materi dengan menggunakan metode, strategi, pendekatan belajar yang sesuai, sehingga dengan mudah peserta didik untuk memahami dan merespon 
materi pembelajaran tersebut. Teknik penjelasan materi pembelajaran dapat diulang 2 ataupun $3 \mathrm{kali}$, hal ini untuk mengakses peserta didik yang lemah tingkat pemahaman (kognitif) ataupun tindakan (psikomotorik) hingga afektif. Pada akhir pembelajaran guru harus memberikan post-test dengan soal yang sama dengan pre-test, untuk mengetahui hasil pembelajaran setiap tatap muka belajar.

Iskandarwassid dkk. (2008: 6) mengkategori-kan menjadi empat(4) strategi dasar dalam proses pembelajaran: 1) mengidentifikasi serta menetapkan spesifikasi dan kualifikasi perubahan tingkah laku dan kepribadian anak didik sebagaimana yang diharapkan; 2) memilih sistem pendekatan pembelajaran berdasarkan aspirasi dan pandangan hidup masyarakat; 3) memilih dan menetapkan prosedur, metode dan teknik pembelajaran yang dianggap paling tepat dan efektif sehingga dapat dijadikan pegangan oleh pengajar dalam menunaikan tugas mengajarnya; 4) menetapkan norma-norma dan batas minimal keberhasilan atau kriteria serta standar keberhasilan sehingga dapat dijadikan umpan balik untuk penyempurnaan sistem instruksional yang bersangkutan secara keseluruhan.

Kerjasama atau suatu teamwork dijiwai oleh suatu konsentrasi untuk suatu kebutuhan dan opini antara yang satu dengan yang lain. Sungguhpun tidak nyata dan dominan, kerjasama nyata menunjukkan suatu kenyataan yang berbeda. Dimana tujuan yang dominan pada seorang guru sebagai pemegang kendali di kelas, kerjasama tertuju antara peserta didik dan fungsi seorang guru sebagai satu team. Interaksi dari kerjasama dan kekuatan yang dinamis sebagai suatu kekuatan sentra antara hubungan guru dan peserta didik. Banyak strategi bisa diperlukan hingga tingkat kerjasama.

Sedangkan Al-Tabany (2015: 11) mengatakan bahwa, salah satu perubahan paradigma pembelajaran tersebut yaitu orientasi pembelajaran yang semula berpusat pada guru (teacher centered) beralih berpusat pada murid (students centered); metodologi yang semula lebih didominasi ekspositori berganti ke partisipatori; dan pendekatan yang semula lebih banyak bersifat tekstual berubah menjadi kontekstual. Semua perubahan ini dimaksudkan untuk memperbaiki mutu pendidikan baik dari segi proses maupun hasil pendidikan.

Memperhatikan beberapa teori yang disampaikan oleh para pakar tersebut, maka dapat di sentesiskan bahwa kegiatan pembelajaran adalah suatu proses kegiatan interaksi antara guru atau pendidik dengan peserta didiknya. Suatu proses kegiatan melalui perubahan, proses kegiatan interaksi tersebut peserta didik dapat mengalami perubahan segala kompetensi mereka, baik kemampuan dalam ranah kognitif, afektif maupun psikomotorik. Pemecahan-pemecahan masalah pada materi yang telah diujikan awal, penjelasan pokok materi dengan menggunakan metode, strategi, pendekatan belajar yang sesuai, sehingga dengan mudah peserta didik untuk memahami dan merespon materi pembelajaran tersebut. Teknik penjelasan materi pembelajaran dapat diulang 2 ataupun $3 \mathrm{kali}$, hal ini untuk mengakses peserta didik yang lemah tingkat pemahaman (kognitif) ataupun tindakan (psikomotorik) hingga afektif.

Dalam proses atau kegiatan pembelajaran, seorang guru harus menggunakan jadwal pelajaran yang telah disiapkan, secara resmi telah ditanda-tangani oleh yang terkait misal wali kelas dan mengetahui wakil atau kepala sekolah langsung. Untuk pertemuan atau tatap muka antara guru dan peserta didik, biasanya 12 sampai dengan 18 kali pertemuan setiap satu semester. Sedangkan untuk satu (1) 
jam belajar biasanya antara 40 hingga 50 menit. Sedangkan langkah-langkah dalam pembelajaran di kelas sesuai dengan langkah-langkah yang telah disusun didalam RPP, dan setiap akhir semester di evaluasi masih apakah masih sesuai atau tidak, apabila tidak sesuai masa kini maka perlu perubahan atau perbaikan.

Di kelas, pada saat memberikan penjelasan tentang materi yang diajarkan, bisa menggunakan alat bantu (media), dengan strategi ataupun metode pembelajaran yang relevan, bertujuan agar peserta didik akan lebih mudah merespon dan memahami materi yang baru diajarkan tersebut. Cara penjelasan perlu diulang 2 atau 3 kali, agar peserta didik tidak ada yang tertinggal, seluruhnya akan lebih mudah memahami materi tersebut. Berikan latihan-latihan soal dan berikan pula cara-cara menjawab soal-soal dengan mudah dan benar. Demikian pula pada saat memberikan tes; postest, mid-test, UAS maka berikan sesuai dengan materi yang telah diajarkan. Pada akhirnya, seluruh rangkaian kegiatan mulai penyusunan RPP hingga proses pembelajaran hingga tes, perlu di evaluasi mana yang harus diubah atau diperbaikan dan mana yang masih relevan digunakan.

Pada awal telah dijelaskan bahwa seorang guru atau pendidik yang profesional harus memahami dan dapat mengimplementasikan fungsi manajemen dalam pembelajaran, agar lebih efektif dan efesien. Di Indonesia lebih dikenal dengan delapan (8) standar pendidikan yang harus dicapai dalam menghasilkan lulusan pendidikan dasar dan menengah, yang didapatkan pada Permendiknas No 23 Tahun 2006 hingga Permendikbud No 20 Tahun 2016. Sesungguhnya, 8 standar pendidikan nasional Republik Indonesia yang isinya banyak pengembangan fungsi manajemen yang disesuaikan dengan situasi dan budaya bangsa Indonesia.

Profesi guru atau pendidik yang memiliki tugas pekerjaan bukan hanya mengajarkan materi dalam proses pembelajaran, namun dituntut pula untuk dapat memberikan bimbingan, konseling, dan keteladanan dalam akhlak atau perilaku yang berbudi luhur. Hal yang tidak kalah penting dimana seorang profesi guru atau pendidik harus menjadi administrator yang baik. Oleh sebab itu, seorang guru atau pendidik harus memiliki kompetensi pedagogik, kepribadian, sosial dan profesional.

Kompetensi bagi profesi guru atau pendidik yang memiliki tugas pekerjaan bukan hanya mengajarkan materi dalam proses pembelajaran, namun dituntut pula untuk dapat memberikan bimbingan, konseling, dan keteladanan dalam akhlak atau perilaku yang berbudi luhur. Hal yang tidak kalah penting dimana seorang profesi guru atau pendidik harus menjadi administrator yang baik. Oleh sebab itu, seorang guru atau pendidik harus memiliki kompetensi pedagogik, kepribadian, sosial dan profesional.

Kegiatan pembelajaran adalah suatu proses kegiatan interaksi antara guru atau pendidik dengan peserta didiknya. Suatu proses kegiatan melalui perubahan, proses kegiatan interaksi tersebut peserta didik dapat mengalami perubahan segala kompetensi mereka, baik kemampuan dalam ranah kognitif, affektif maupun psikomotorik. Pemecahan-pemecahan masalah pada materi yang telah diujikan awal, penjelasan pokok materi dengan menggunakan metode, strategi, pendekatan belajar yang sesuai, sehingga dengan mudah peserta didik untuk memahami dan merespon materi pembelajaran tersebut. Teknik penjelasan materi pembelajaran dapat diulang 2 ataupun 3 kali, hal ini untuk mengakses peserta didik yang lemah tingkat pemahaman (kognitif) ataupun tindakan (psikomotorik) hingga afektif. 


\section{Siklus I}

Planning

Perencanaan pembelajaran sangat penting dimana untuk menentukan arah kegiatan pembelajaran. Disamping menyiapkan silabus, jadwal pelajaran, program semester, RPP, dan pengembangan materi, metode, strategi, media pembelajaran yang akan digunakan, maka seorang guru harus menyiapkan pula Berita Acara Pembelajaran (BAP), dan presensi untuk mencatat kehadiran siswa.

Acting

Mahasiswa sebagai guru bidang studi menyerahkan RPP kepada dosen pengampu micro-teaching. RPP tersebut dievaluasi, dianalisis oleh dosen pengampu diberikan penilaian. Demikian selanjutnya mahasiswa melaksanakan proses atau kegiatan pembelajaran di kelas micro-teaching. Kegiatan pembelajaran tersebut juga dievaluasi oleh dosen pengampu dan diberikan penilaian.

\section{Actuating}

Dalam pembelajaran, bagaimana mahasiswa sebagai guru bidang studi memulai awal pembelajaran. Bagaimana pengendalian kelas bisa dikuasai dengan baik atau tidak, dapatkah ia menguasai materi pelajaran dengan baik, dapatkah menggunakan media, metode pembelajaran dengan tepat. Keadaan kelas bisa dinamis, aktif atau sebaliknya. Bagaimana pendidik menggunakan dan membagi waktu yang tepat, memberikan tes dan memotivasi anak didiknya agar lebih giat belajar.

\section{Reflecting}

Penelitian lapangan di kelas PPL, biasanya sebelum melaksanakan PPL maka mahasiswa harus mengikuti micro-teaching. Pada saat peneliti mengampu beberapa mahasiswa dalam persiapan PPL, memberikan tes tentang perencanaan pembelajaran dengan menilai hasil penyusunan RPP. Dari 6 mahasiswa banyak diketemukan kurang memahami betul tentang penyusunan RPP tersebut.

Kebanyakan kekurangan tersebut antara lain; penentuan tujuan pembelajaran hanya mengambil dari indikator silabus tidak disesuaikan dengan materi bahan ajar untuk pelaksanaan dan target pembelajaran. Pemilihan teknik, metode pembelajaran kurang sesuai dengan pengembangan materi ajar. Sumber materi atau bahan ajar hanya dituliskan buku-buku yang relevan. Soal untuk tes baik pretest ataupun post-test tidak disiapkan dengan baik.

Pada akhir pelaksanaan micro-teaching mahasiswa tersebut dipantau dan dinilai mulai dari penyusunan RPP, hingga pelaksanaan Pembelajaran di kelas micro-teaching, nilai yang didapatkan sebagai berikut; nilai terendah 65, ratarata $=67,167$, nilai tertinggi 70 , dan presentase hasil pembelajaran lulus di atas KKM sama dengan 66, maka lulus $66,67 \%$ dan tertinggal atau tidak lulus $=33,33 \%$. Hasil tersebut digambarkan pada Grafik 1 dan Grafik 2, oleh karena belum mencapai target $80 \%$ maka penelitian dilanjutkan pada siklus II. Bagaimana yang tidak lulus, perlu diberikan remedial agar pada siklus II dapat mencapai peningkatan dan bisa lulus. 


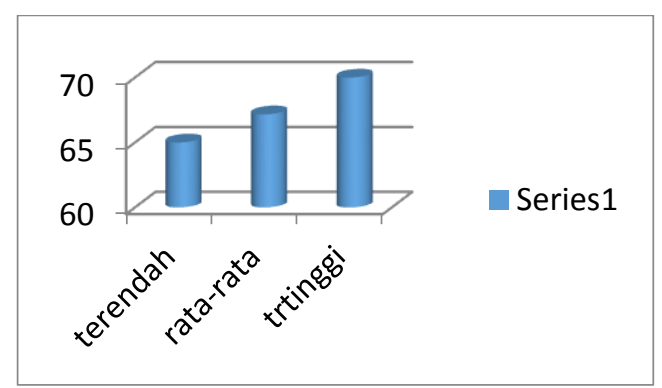

Grafik 1. Nilai Hasil Micro Teaching

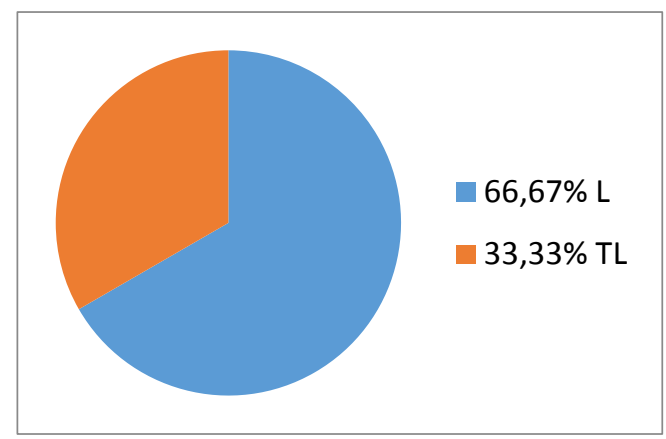

Grafik 2. Presentase Kelulusan

\section{Siklus II}

Planning

Perencanaan pembelajaran perlu dipersiapkan dengan baik, silabus, jadwal, dan RPP. Pada siklus sebelumnya telah diberikan hasil evaluasi tentang penyusunan RPP, untuk pembelajaran di micro-teaching. Oleh karena itu, maka pada siklus II mahasiswa telah memperbaiki penyusunan RPP. tersebut, untuk dipersiapkan pada PPL. Selanjutnya mahasiswa bekerjasama dengan guru pamong, menyiapkan BAP, dan presensi untuk daftar kehadiran siswa.

Acting

Materi pelajaran yang telah dipersiapkan dengan baik pada saat menyusun RPP., maka mahasiswa harus menguasai materi tersebut dengan baik, sehingga dapat menyampaikan kepada siswa biasanya 2 atau 3 kali diulang agar siswa benar-benar memahami materi tersebut. Banyak berbagai cara untuk menyampaikan materi pelajaran, dapat menggunakan metode, strategi, maupun media yang relevan dalam masa pembelajaran saat ini. Bahkan guru bisa memberikan contoh-contoh untuk mempermudah pemahaman siswa-siswa dalam mempelajari materi tersebut.

\section{Actuating}

Perlunya kajian atau evaluasi proses pembelajaran sebelumnya untuk merubah atau memperbaiki pada proses pembelajaran berikutnya. Guru harus berupaya bagaimana agar supaya kelas bisa kondusif dan aktif dalam pembelajaran, siswa bisa berdiskusi dengan teman yang lain. Guru bisa saja membentuk kelompok belajar, dan tiap kelompok terdiri dari yang pinter dicampur dengan yang biasa saja, sehingga antar kelompok bisa bersaing dengan kelompok yang lain. Demikian seterusnya, guru harus bisa memberikan motivasi atau dorongan belajar untuk mencapai keberhasilan. 


\section{Reflecting}

Pada saat menyerahkan RPP yang telah diperbaiki. Perbaikan RPP. tersebut harus diberikan nilai untuk menopang hasil PPL di Sekolah yang dituju. Sehingga nilai tugas perbaikan RPP dan hasil penilaian dalam proses pembelajaran di sekolah menengah, sebagai nilai akhir PPL.

Nilai hasil akhir PPL di gabungkan dengan nilai perbaikan RPP, maka didapatkan nilai terendah 76 rata-rata $=80,3333$ dan nilai tertinggi 85 , digambarkan pada Grafik 3 dan Grafik 4. Presentase kelulusan tidak lulus 0, dan lulus $100 \%$, maka melebihi target belajar dan penelitian hanya sampai pada siklus II atau tidak dilanjutkan ke siklus III.

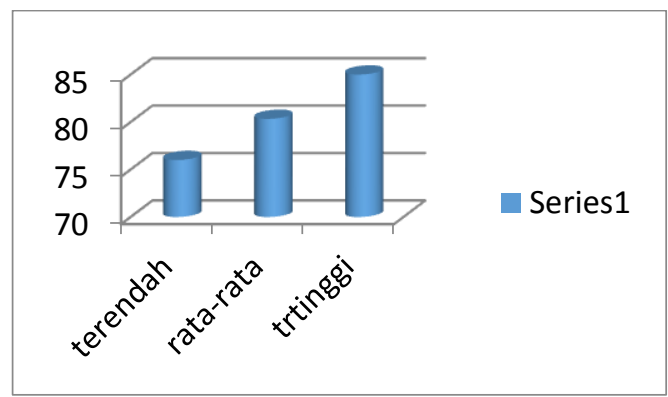

Grafik 3. Hasil Nilai PPL.

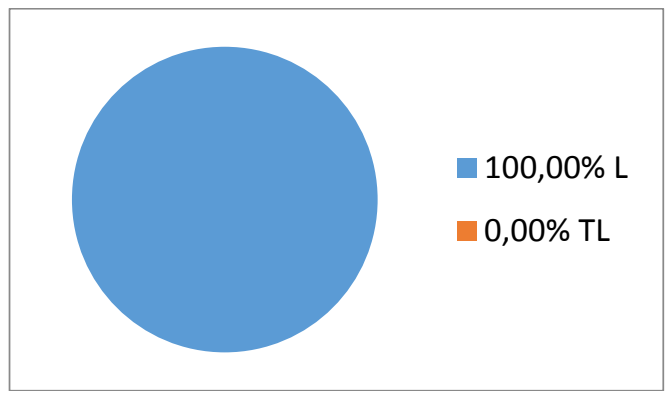

Grafik 4. Presentase Kelulusan

\section{KESIMPULAN}

Bagaimanapun juga seorang pendidik wajib memahami dan dapat menelaah untuk menggunakan kurikulum atau silabus dengan baik, sebab kurikulum sebagai menu pembelajaran tentu digunakan sebagai acuan setiap pendidik. Demikian juga kalender pendidikan sangat dibutuhkan bagi seorang pendidik, karena dapat digunakan untuk menyusun program dalam jangka tertentu, contoh program semester. Jadwal pelajaran sangat penting bagi seorang pendidik yang akan melaksanakan kegiatan pembelajaran di ruang kelas. Tak dapat dibayangkan, bila tidak ada jadwal pelajaran maka apa yang terjadi. Salah menentukan jadwal saja dapat berbenturan atau bentrok antara jadwal guru yang satu dengan lainnya. Maka jadwal pelajaran perlu disiapkan secara baik dan teliti agar tidak terjadi masalah dalam kegiatan pembelajaran.

Jelas bahwa seorang pendidik yang profesional harus memiliki kemampuan dan keterampilan tentang pengelolaan kelas, atau manajemen kelas dengan baik, menguasai tentang fungsi manajemen dan mampu menerapkannya dengan baik, 
memahami tentang 8 standar pendidikan dengan runtut dan baik. Hal ini dapat dikatakan bila seorang guru menguasai manajemen kelas dengan baik maka tugas pokok mengajar di kelas akan berhasil baik secara efektif. Jelas bahwa seorang pendidik perlu persiapan mengajar harus dilakukan dengan matang, bukan hanya RPP yang baik, namun juga persiapan fisik, mental, dan segala upaya untuk dapat melaksanakan tujuan pembelajaran dengan baik.

Evaluasi seluruh kegiatan bagi guru sangat penting dilakukan sebab akan dapat memperbaiki langkah-langkah pembelajaran berikutnya. Disisi lain, evaluasi perlu dilakukan mulai dari perencanaan, proses pembelajaran, bagaimana penggunaan media, metode pembelajaran dll. apakah telah digunakan dengan sebaiknya. Apabila didapat metode yang tidak sesuai maka RPP pada semester berikutnya perlu diubah atau diperbaiki, khususnya penggunaan metode pembelajaran, demikian pula untuk hal-hal yang lain. Demikian pula soal tes juga perlu untuk di evaluasi, karena bisa terjadi bila siswa tidak bisa menjawab dengan benar, bukan karena mereka bodoh, tapi ada kemungkinan soal tesnya yang tidak bisa dipahami, ditelaah dengan baik atau ambigo, bisa terjadi dua atau lebih jawaban yang benar.

Berdasarkan penjelasan tersebut di atas, maka dapat disimpulkan bahwa; terdapat peningkatan hasil belajar mahasiswa dalam kelas micro-teaching dan PPL. Oleh karena itu diharapkan profesi seorang pendidik akan lebih profesional dalam melaksanakan pembelajaran di kelas bila menguasai manajemen kelas dengan baik, memahami betul tentang fungsi manajemen dan bagaimana untuk meng-implementasikannya. Disisi lain, seorang pendidik harus memahami tentang 8 standar pendidikan dan dapat bekerjasama dengan institusinya bagaimana untuk mengimplementasikan standar pendidikan tersebut. Bagaimana pula mengimplementasikan kompetensi yang lain termasuk; kompetensi pedagogik, kompetensi kepribadian dan kompetensi sosial.

Bagi seorang guru atau pendidik wajib menyiapkan soal yang digunakan untuk pretes atau postes. Oleh sebab itu, durasi waktu untuk pelaksanaan tes (pretes atau postes) disesuaikan dengan proses kegiatan pembelajaran misalkan: 15 menit. Berdasarkan penjelasan tersebut di atas, maka dapat disimpulkan bahwa; bila pembelajaran dilaksanakan dengan baik maka hasil belajar akan lebih sukses dan berhasil baik. Sebaliknya, bila kegiatan pembelajaran tanpa perencanaan pembelajaran yang baik maka hasil pembelajaran tidak dapat optimal. Terbukti bahwa setelah diberikan penjelasan dalam penyusunan RPP sesuai pakem dan pengelolaan pembelajaran yang sistematis maka terdapat kenaikan atau peningkatan hasil belajar yang signifikan (lihat di hasil penelitian sebelumnya).

Implikasi terhadap manajemen kelas, pengelolaan kelas perlu diterapkan bagi seorang pendidik sebagai profesinya. Seorang pendidik harus menerapkan fungsi manajemen mulai dari perencanaan pembelajaran yang harus konsisten disiapkan bagi para calon pendidik, ataupun mahasiswa tingkat akhir yang akan melaksanakan PPL. Kemudian bagaimana untuk melakukan pengelolaan kelas dengan baik, teknik komunikasi, cara atau strategi apa agar dapat berinteraksi dengan siswa. Seorang pendidik yang profesional dituntut bagaimana dapat menciptakan kelas yang aktif, dapat berdebat, berdiskusi tentang materi ajar yang baru diajarkan. Seorang pendidik harus dapat menumbuhkan motivasi belajar yang kuat bagi siswanya, rasa percaya diri diajarkan bagaimana untuk bertanya, 
selalu ditunjukkan kekurangan atau masalah mereka dan apa solusinya yang dapat dilakukan.

Sebaiknya setiap guru atau pendidik yang profesional harus memahami dan menguasai tentang fungsi manajemen pada manajemen kelas. Karena apabila seorang guru atau pendidik sebagai profesinya memahami fungsi manajemen dengan baik maka akan dapat mengelola pembelajaran yang lebih efektif dan efesien. Seorang pendidik atau calon guru harus dapat menerapkan fungsi manajemen dari mulai dari perencanaan pembelajaran, pengelolaan kelas, soalsoal ujian, sistem penilaian yang baik dll. Seluruhnya agar dievaluasi setiap akhir semester agar pada pembelajaran berikutnya dapat ditingkatkan lebih baik.

Seorang pendidik harus dapat bekerjasama dengan institusinya, memahami betul tentang 8 standar pendidikan dan bagaimana penerapannya. Perencanaan pembelajaran setiap awal semester disiapkan dengan perhatian penuh agar proses kegiatan pembelajaran dapat dilaksanakan dengan baik sesuai dengan perencanaan tersebut. Pada akhir semester, perencanaan pembelajaran yang telah dilaksanakan tersebut dievaluasi, atau dianalisis hingga didapatkan masalah atau kekurangan dan ada pula bagian-bagian yang sukses. Untuk bagian yang bermasalah tentu diadakan perbaikan pada pembelajaran berikutnya, namun untuk bagian yang sukses tentu dapat dilanjutkan pada semester gasal/genap berikutnya.

\section{REFERENSI}

Al-Tabany, T. I. B. (2015). Mendesain Model Pembelajaran Inovatif, Progresif, Dan Konteksual. Jakarta: Prenada Media.

Beaty-O'Ferrall, M. E., Green, A., \& Hanna, F. (2010). Classroom management strategies for difficult students: Promoting change through relationships. Middle School Journal, 41(4), 4-11.

Burke, C. D., \& Stone, D. R. (1975). A research-based learning processes model for developing and evaluating teacher education curricula. Journal of Teacher Education, 26(3), 235-241.

Iskandarwassid., \& Sunendar, D. (2008). Strategi Pembelajaran Bahasa. Bandung: Remaja Rosdakarya.

Marzano, R. J., \& Marzano, J. S. (2003). Building classroom relationships. Educational Leadership, 61(1), 6-13.

Mukhtar, M. (2012). Manajemen Sistem. Jakarta: BPJM FIP UNJ.

Mukhtar, M. (2013). Pengawasan Pendidikan. Jakarta: BPJM Press

Mondy, R. W., Noe, R. M., \& Premeaux, S. R. (2010). Human Resource Management. New Jersey: Prentice Hall International, Inc.

Parkay, F. W., Anctil, E. J., \& Hass, G. (2010). Curriculum Leadership: Readings for Developing Quality Educational Programs. NY: Prentice Hall.

Patel, V. B. (2013). Management Theory in context of Modern Trend. International Journal of Research in all Subjects in Multi Languages, 1(4), 22-24.

Robbins, S. P., \& Coulter, M. (2007). Principles of management. Tehran: Office of Cultural Studies.

Simon, H. A. (1997). Administrative Behavior: A Study Decision-Making Process an Administrative Organizations. NY: The Free Press. 
Sudjoko S. (2015). Kompensasi, Iklim Kerja, dan Motivasi terhadap Kepuasan Kerja [Unpublished manuscript]. Program Studi Manajemen Pendidikan, Universitas Negeri Jakarta.

Sufyarma, M. (2003). Kapita selekta manajemen pendidikan. Bandung: Alfabeta.

Yuliani, R., Suntoro, I., \& Kandar, S. (2015). Implementasi Manajemen Pendidikan Sekolah Dasar Negeri 1 Gisting Bawah. Jurnal Manajemen Mutu Pendidikan, 3(2), 1-16. 